\title{
Stimulation of vascular protein synthesis by activation of oestrogen receptor $\beta$
}

\author{
M Liang, E Ekblad, J-Å Gustafsson ${ }^{1}$ and B-O Nilsson \\ Department of Physiological Sciences, Lund University, BMC F12, S-221 84 Lund, Sweden \\ ${ }^{1}$ Department of Medical Nutrition, Karolinska Institute, Novum, S-141 86 Huddinge, Sweden \\ (Requests for offprints should be addressed to B-O Nilsson, Department of Physiological Sciences, Lund University, BMC F12, S-221 84 Lund, Sweden; \\ Email: bengt-olof.nilsson@mphy.lu.se)
}

\begin{abstract}
The objective of this study was to investigate the effects of oestrogen receptor (ER) $\beta$ activation on vascular protein synthesis and protein expression. Nuclear immunoreactivity towards ER $\beta$ was observed abundantly in vascular smooth muscle and endothelial cells of mouse aorta. No ER $\alpha$-positive cell nuclei were observed. In aorta from ovariectomized mice, treatment with the selective ER $\beta$ agonist genistein $(100 \mathrm{nM})$ for $24 \mathrm{~h}$ increased $\left[{ }^{3} \mathrm{H}\right]$ leucine incorporation by about $30 \%$. This effect was prevented by the ER blocker ICI $182780(10 \mu \mathrm{M})$. Although genistein treatment stimulated protein synthesis, it caused no change in total protein determined either by the Lowry method on tissue homogenate or by densitometric scanning of
\end{abstract}

protein bands $(10-220 \mathrm{kDa})$ separated by SDS-PAGE. Separation of $\left[{ }^{35} \mathrm{~S}\right]$ methionine-labelled proteins by SDS-PAGE did not reveal the protein(s) stimulated by genistein. DNA synthesis was not affected by $100 \mathrm{nM}$ genistein, suggesting that genistein-induced stimulation of protein synthesis is not part of a growth response. Protein expression, determined by SDS-PAGE, was similar in aorta from ER $\beta$-knockout and wild-type mice, suggesting that expression of vascular proteins does not depend solely on a functional ER $\beta$ gene. We suggest that activation of vascular ER $\beta$ stimulates synthesis of proteins and that this response is not associated with vascular growth.

Journal of Endocrinology (2001) 171, 417-423

\section{Introduction}

Two oestrogen receptor (ER) subtypes $(\alpha$ and $\beta$ ) have been isolated and cloned (Green et al. 1986, Greene et al. 1986, Kuiper et al. 1996). Some domains of ER $\beta$ cDNA are highly homologous to those of ER $\alpha$ cDNA and the overall homology between ERs $\beta$ and $\alpha$ is about 50\%. Upon ligand binding and activation, the receptor-ligand complex interacts with specific oestrogen response elements located in the promoter region of oestrogen-responsive genes, regulating their transcriptional activity (for reviews see Grandien et al. 1997, Muramatsu \& Inoue 2000). Target genes for activated ER $\beta$ and patterns of protein expression regulated by this receptor are important issues and are in the focus of current research.

Oestrogen increases uterine blood flow during pregnancy and during the oestrus cycle, but the mechanism(s) responsible for this effect remains unclear (Mendelsohn \& Karas 1999). Vascular expression of mRNA for ER $\beta$ has been demonstrated in rat aorta and carotid artery and in mouse aorta (Iafrati et al. 1997, Lindner et al. 1998, Mäkelä et al. 1999). Recently, we have detected nuclear expression of $E R \beta$ protein in different vascular segments of female rats (Andersson et al. 2001). Abundant expression of ER $\beta$ was detected in medial smooth muscle and endothelial cells. In contrast, ER $\alpha$ was observed only in occasional uterine vessel smooth muscle and endothelial cells. We have previously shown that both the maximal noradrenaline-evoked effect and the sensitivity to noradrenaline are similar in aorta from ER $\beta$-knockout and wild-type mice (Nilsson et al. 2000). These data thus suggest similar expression of vascular proteins in ER $\beta$ knockout and wild-type mice.

The aim of the present study was to investigate the importance of vascular ER $\beta$ in the regulation of DNA and protein synthesis. Protein and DNA synthesis in aorta from ovariectomized mice was determined by incorporation of $\left[{ }^{3} \mathrm{H}\right]$ leucine, $\left[{ }^{35} \mathrm{~S}\right]$ methionine and $\left[{ }^{3} \mathrm{H}\right]$ thymidine after stimulation with the selective $\operatorname{ER} \beta$ agonist, genistein. Proteins were separated by SDS-PAGE and protein expression in vascular tissue from ER $\beta$-knockout female mice was compared with that in wild-type mice using SDS-PAGE. The results suggest that ER $\beta$ activates vascular protein synthesis and that this is not part of a growth response. 


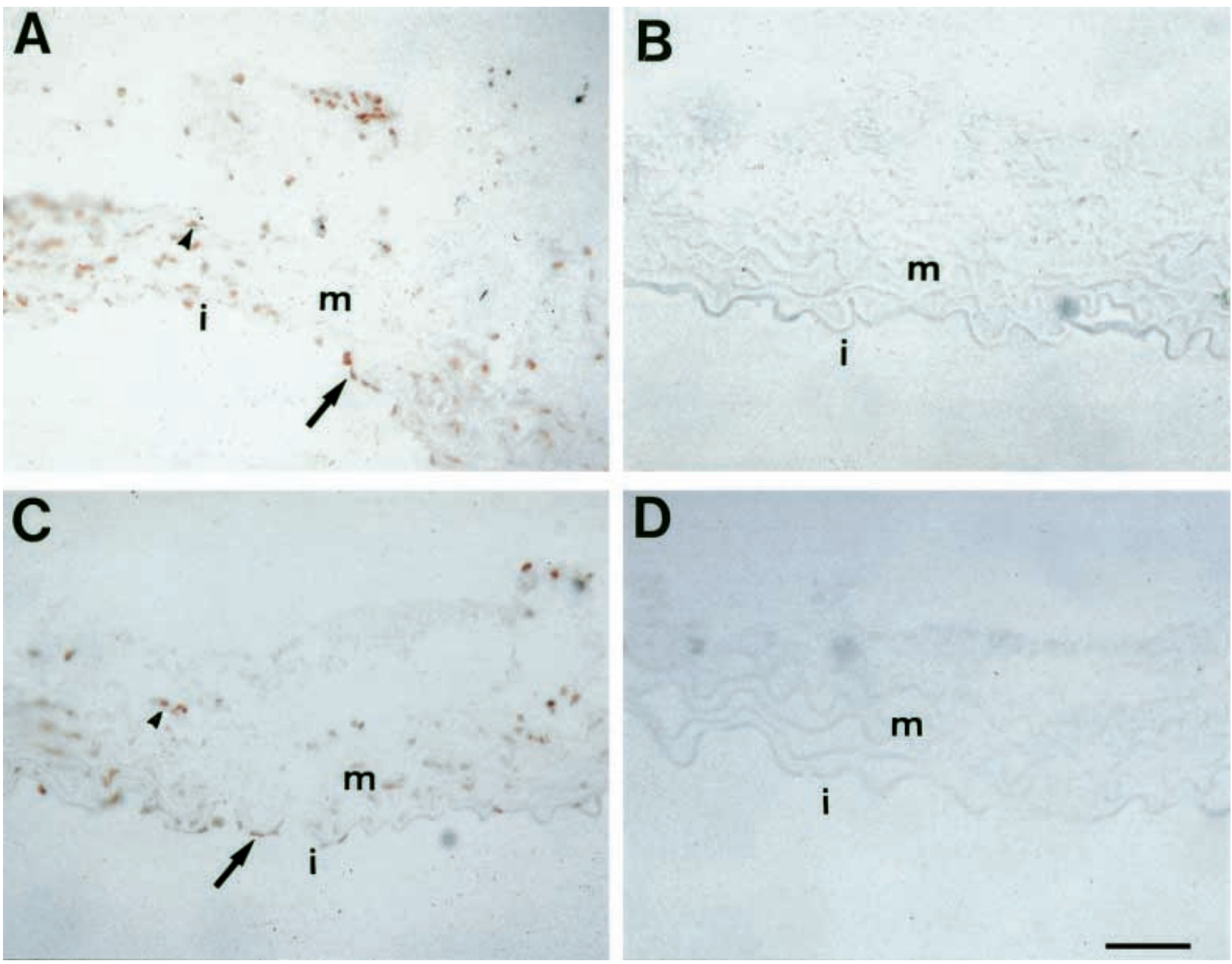

Figure 1 Immunostainings with ER $\beta$ antibody (dilution 1:1000). Nuclear expression of ER $\beta$ was observed in medial smooth muscle and in endothelial cells of aorta from unoperated (A) and ovx (C) mice. Arrows show positively stained endothelial cells of the tunica intima (i); arrowheads show positively stained smooth muscle cells of the tunica media $(\mathrm{m})$. No immunoreactivity was observed if the primary antibody was omitted (B and D). Bar represents $50 \mu \mathrm{m}$ (for A-D).

\section{Materials and Methods}

\section{Animals and tissue}

Adult (3-month-old) NMRI female mice (24-30 g) were anaesthetized with pentobarbital sodium (75 $\mathrm{mg} / \mathrm{kg}$ i.p.) and the ovaries removed bilaterally. After a 7 -day period of recovery with food and water available ad libitum, the ovariectomized (ovx) mice were killed by cervical dislocation. Mice were fed a standard rodent diet (R36, Lactamin, Stockholm, Sweden). This diet contains about $5 \%$ soy bean. Although soy bean is rich in phytoestrogens such as genistein, this was unlikely to exert any influence, as the experiments were performed in vitro. The experiments were approved by the Ethics Committee at Lund University. The thoracic aorta from the diaphragm to the aortic arch was removed under sterile conditions and dissected free from fat and connective tissue in cold
$\mathrm{Ca}^{2+}$-free Krebs-buffered solution (for composition, see below). The aorta was cut open through the lumen and divided into three pieces of tissue. The tissues were incubated with or without genistein $(10-10000 \mathrm{nM})$ in Petri dishes with $\mathrm{Ca}^{2+}$-containing $(2.5 \mathrm{mM})$ Krebs buffer or Dulbecco's Modified Eagle's Medium (Sigma Chemicals, St Louis, MO, USA) without phenol red at $37^{\circ} \mathrm{C}$ in a water-jacketed tissue/cell incubator for $24 \mathrm{~h}$. The pure ER blocker ICI 182780 was introduced $1 \mathrm{~h}$ before genistein and was then present throughout the incubation.

Adult (3-month-old) female mice lacking functional $\operatorname{ER} \beta(-/-)$ were generated by targeted disruption of exon three of the $E R \beta$ gene as described previously (Krege et al. 1998). Their wild-type $(+/+)$ litter mates served as controls. Lack of ER $\beta$ in $-/-$ mice was confirmed by RT-PCR for ER $\beta$ mRNA and by Western blot showing 

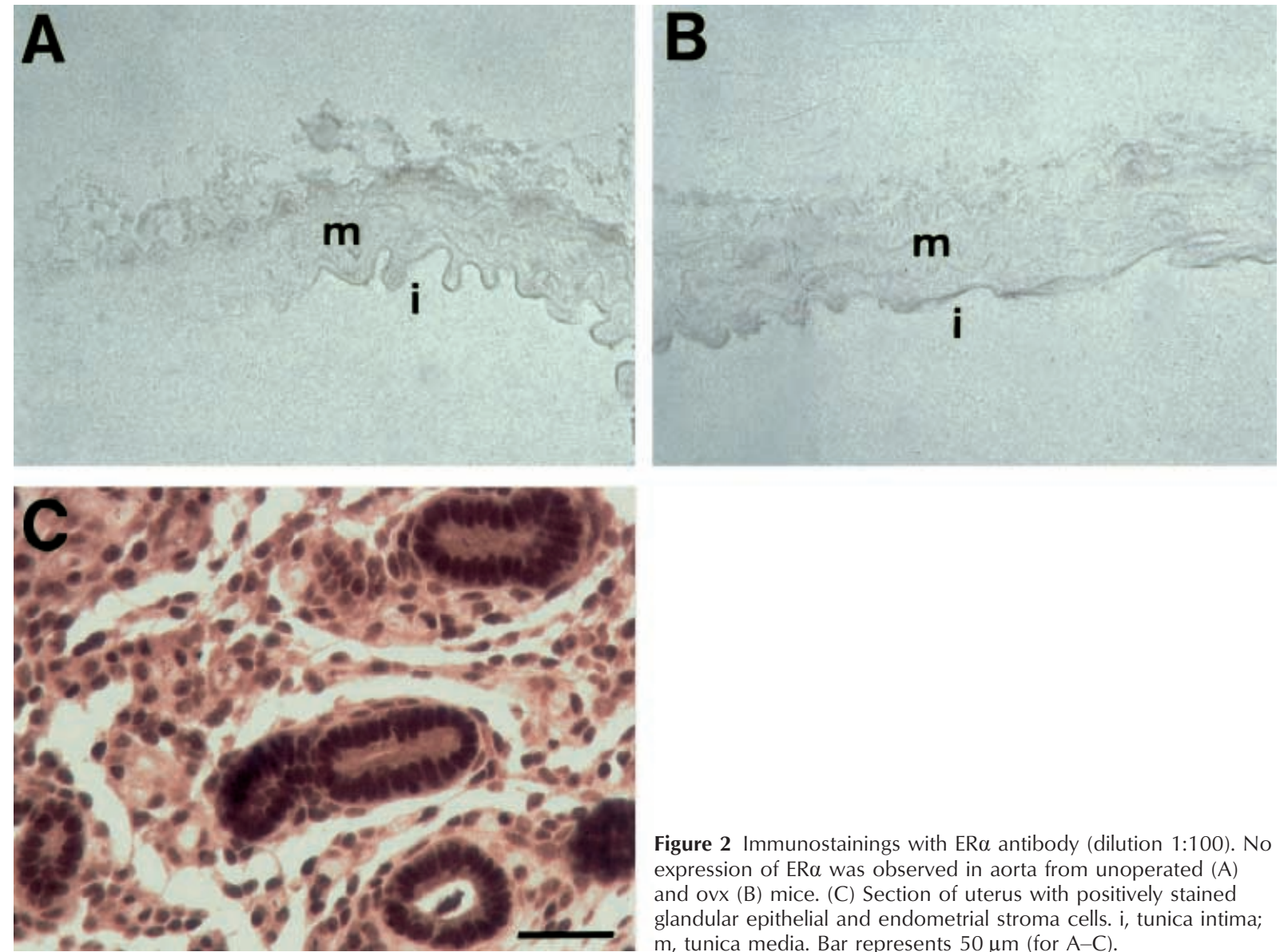

Figure 2 Immunostainings with ER $\alpha$ antibody (dilution 1:100). No expression of ER $\alpha$ was observed in aorta from unoperated (A) and ovx (B) mice. (C) Section of uterus with positively stained glandular epithelial and endometrial stroma cells. i, tunica intima; $\mathrm{m}$, tunica media. Bar represents $50 \mu \mathrm{m}$ (for $\mathrm{A}-\mathrm{C}$ ).

the absence of ER $\beta$ mRNA and protein in $-/-$ but not in $+/+$ mouse tissues.

\section{Immunocytochemistry}

Tissue specimens were fixed in $4 \%$ buffered formalin solution, dehydrated and then embedded in paraffin. The preparations were cut in 4- $\mu \mathrm{m}$ transverse sections, deparaffinized and treated for $15 \mathrm{~min}$ with citrate buffer $(\mathrm{pH} 6 \cdot 0)$ in a microwave oven before immunostaining (Shi et al. 1991). The ER $\beta$ antibody (code no ER $\beta$ 503) was raised in chicken and has been characterized previously (Saji et al. 2000, Andersson et al. 2001). The ER $\alpha$ antibody was a monoclonal mouse antibody (ER1D5; Dako A/S, Glostrup, Denmark). In preliminary experiments, the dilution of $\operatorname{ER} \beta$ and $\operatorname{ER} \alpha$ antibodies was titrated to achieve optimal nuclear staining. The slides were stained in an automatic immunostainer TechMate 500 (Ventana Biotek, Tuscon, AZ, USA) with DAKO ChemMate Detection Kit peroxidase/3-3' diaminobenzidine. For ER $\beta$, the secondary antibody was a biotinylated rabbit anti-chicken IgY (1:5000, Jackson Immuno Research
Laboratories, West Grove, PA, USA). At each staining, a positive control (uterus) was run in parallel; for negative controls, the primary antibodies were omitted. No immunoreactivity was observed after omission of the ER $\beta$ or the ER $\alpha$ antibody. Tissues for immunocytochemistry were obtained from five mice and at least two stained slides were analysed for each individual tissue.

\section{Determination of DNA and protein synthesis}

After the preincubation with genistein, either radiolabelled thymidine or radiolabelled leucine was added. Ten $\mu \mathrm{Ci}$ [methyl- $\left.{ }^{3} \mathrm{H}\right]$ thymidine or $\mathrm{L}-\left[4,5-{ }^{3} \mathrm{H}\right]$ leucine was present for the last $1 \mathrm{~h}\left(\left[{ }^{3} \mathrm{H}\right]\right.$ thymidine $)$ or the last $18 \mathrm{~h}$ $\left(\left[{ }^{3} \mathrm{H}\right]\right.$ leucine) of the $24 \mathrm{~h}$ incubation with genistein. The incubation was stopped by placing the Petri dishes on ice. The tissue was washed, weighed and homogenized by sonication for $4 \times 10 \mathrm{~s}$ in $5 \mathrm{mM} \mathrm{NaOH}$. Aliquots of the homogenate were precipitated with 5\% trichloroacetic acid (TCA) on ice and centrifuged at 10000 r.p.m. for 2 min at $4{ }^{\circ} \mathrm{C}$. For every determination, double samples were analysed. The pellet was washed twice with 5\% 

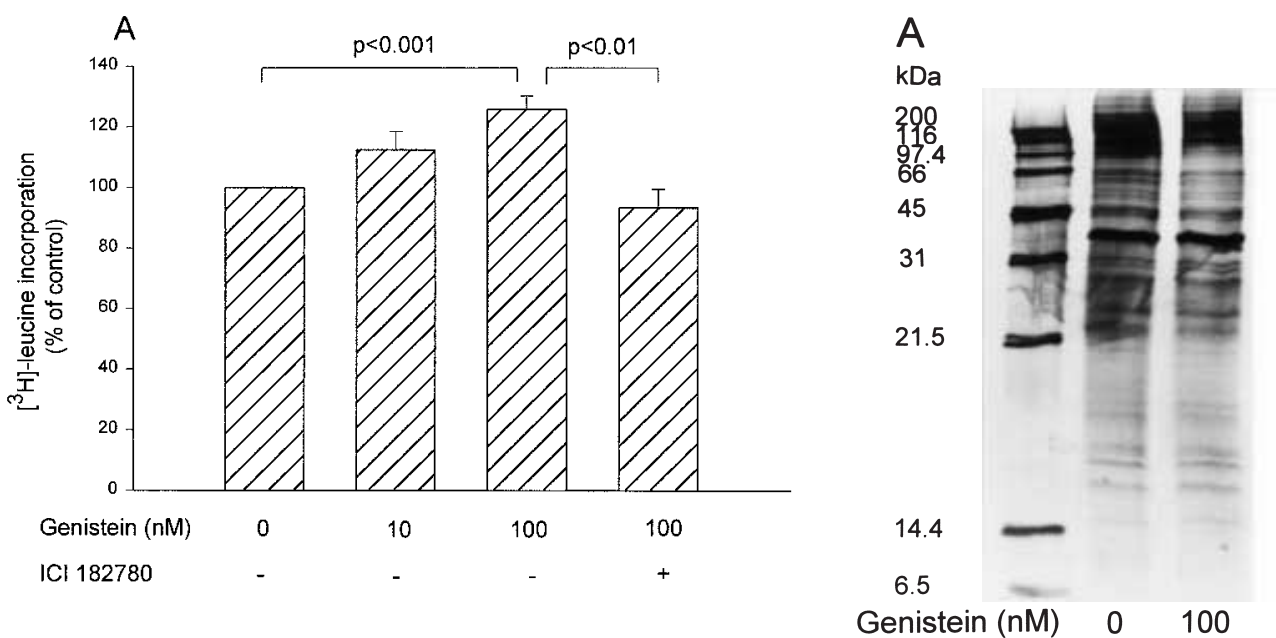

B

Figure 4 Separation of vascular proteins by SDS-PAGE after

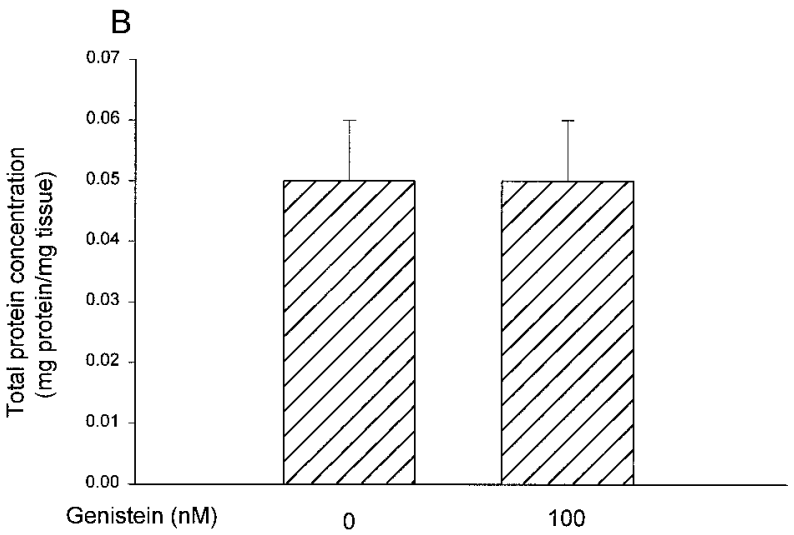

Figure 3 Effects of genistein on protein synthesis (A) and on total protein content $(\mathrm{B})$ in aorta from ovx mice. Protein synthesis was determined by $\left[{ }^{3} \mathrm{H}\right]$ leucine incorporation. The pure ER blocker $\mathrm{ICI}$ $182780(10 \mu \mathrm{M})$ was introduced $1 \mathrm{~h}$ before genistein $(100 \mathrm{nM})$ and was present throughout the incubation. Incorporation of $\left[{ }^{3} \mathrm{H}\right]$ leucine was determined as d.p.m./mg tissue and data are presented as normalized values. Incorporation of radiolabelled leucine in controls, not receiving genistein, was set to $100 \%$. Total protein data are presented as $\mathrm{mg}$ protein/mg tissue wet weight. Values are means \pm S.E.M.; $n=3-6$.

TCA and centrifuged as above and then dissolved in Soluene 350 at room temperature for $2 \mathrm{~h}$. A liquid scintillation cocktail was added and the radioactivity measured in a liquid scintillation counter (Beckman LS6500, Beckman Instruments Inc., CA, USA). Mean radioactivity (d.p.m.) in double samples was calculated. The amount of incorporated $\left[{ }^{3} \mathrm{H}\right]$ thymidine and $\left[{ }^{3} \mathrm{H}\right]$ leucine was computed as d.p.m./mg tissue.

\section{Determination of total protein and protein separation}

The tissue was weighed and pulverized in liquid $\mathrm{N}_{2}$ and transferred to SDS sample buffer (for composition, see below). The sample buffer volume was $100 \mu \mathrm{l} / \mathrm{mg}$ tissue.

stimulation of aorta from ovx mice with $100 \mathrm{nM}$ genistein. (A) Silver-stained gel (one of three independent experiments). (B) Autoradiograph of $\left[{ }^{35} \mathrm{~S}\right]$ methionine-labelled proteins (one of six independent experiments). In this experiment, radiolabelled methionine was present for $18 \mathrm{~h}$. Separation of proteins were performed on $7 \cdot 5-15 \%$ gels to obtain good separation in the range $10-200 \mathrm{kDa}$. The optical density (OD) of the bands $\left(\mathrm{OD} / \mathrm{mm}^{2}\right)$ was determined using a GS-710 Imaging Densitometer (BioRad) and Quantity One quantitation software (BioRad).

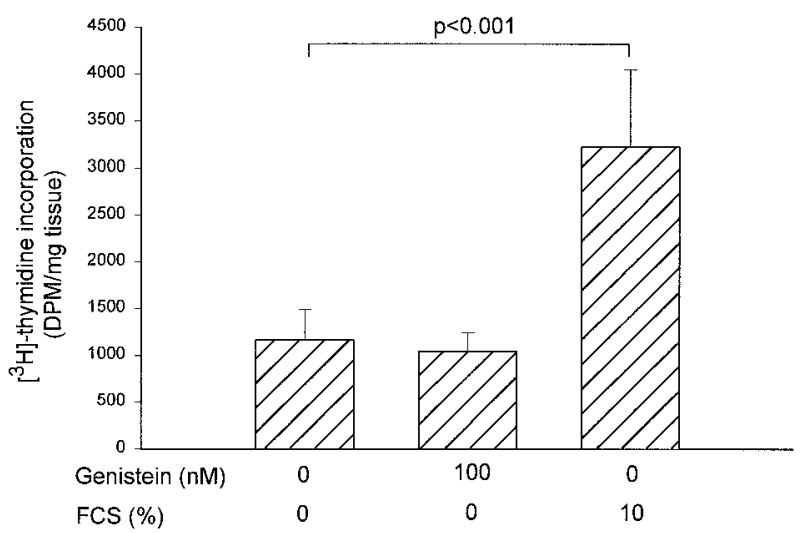

Figure 5 Effects of genistein on DNA synthesis. DNA synthesis was determined by $\left[{ }^{3} \mathrm{H}\right]$ thymidine incorporation. Aorta from ovx mice was incubated with or without $100 \mathrm{nM}$ genistein and $\left[{ }^{3} \mathrm{H}\right]$ thymidine was present for the last $1 \mathrm{~h}$ of incubation. Genistein had no effect on DNA synthesis. The well-known growth factor, fetal calf serum (FCS), was used as positive control. Values are means \pm S.E.M.; $n=3-10$.

After incubation for $30 \mathrm{~min}$ on ice and sonication (10 s), the suspension was boiled for $3 \mathrm{~min}$ and centrifuged at 14000 r.p.m. for $10 \mathrm{~min}$ at $4{ }^{\circ} \mathrm{C}$. Supernatant was collected and total protein was determined by using a BioRad protein assay based on the Lowry method (Lowry et al. 1951). Proteins were separated using SDS-PAGE on a Bio Rad minigel system using 7·5\% and 15\% gels. Protein 


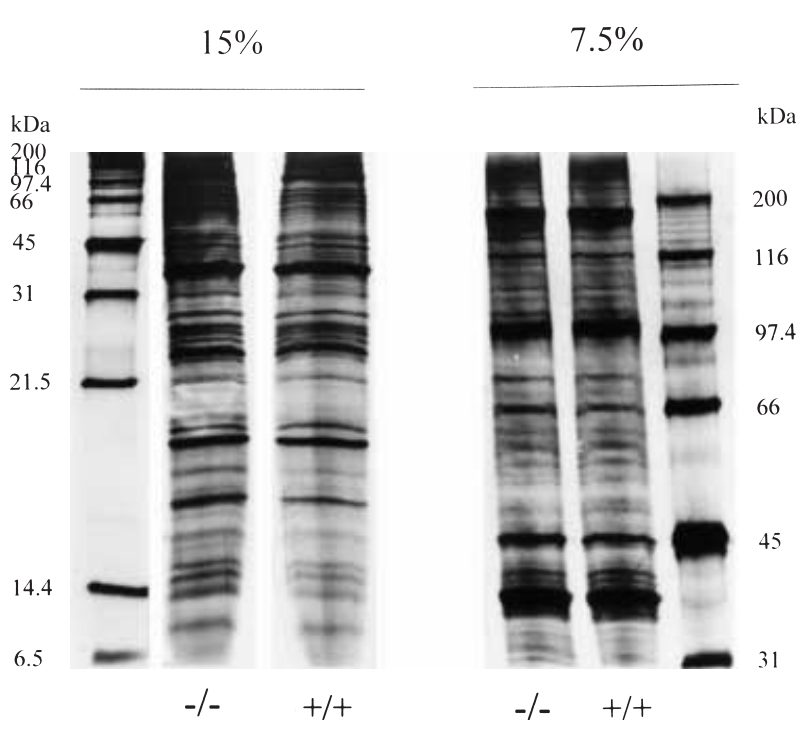

Figure 6 Separation of proteins in aorta from ER $\beta$-knockout $(-/-)$ and wild-type $(+/+)$ mice using SDS-PAGE. Equal amounts of protein were added to each lane. Good separation of proteins between 6 and $200 \mathrm{kDa}$ was obtained by using 7.5\% and $15 \%$ gels. Homogenates from $5-/-$ and $5+/+$ mice were used and $-/-$ and $+/+$ samples were loaded on each gel in duplicate. In all, four $15 \%$ and three $7 \cdot 5 \%$ gels were run. The optical density $(\mathrm{OD})$ of the bands $\left(\mathrm{OD} / \mathrm{mm}^{2}\right)$ was determined using a GS-710 Imaging Densitometer (BioRad) and Quantity One quantitation software (BioRad).

concentration of the homogenate was determined as described above. Equal amounts of protein were always loaded on each lane. After electrophoresis, the gels were silver stained using a silver staining kit from Amersham Pharmacia Biotech AB, Uppsala, Sweden.

\section{Autoradiography of $\left[^{35}\right.$ S]methionine incorporation}

After preincubation with $100 \mathrm{nM}$ genistein, $25 \mu \mathrm{Ci}$ radiolabelled $\left(\left[{ }^{35} \mathrm{~S}\right]\right)$ methionine was added. The isotope was present for the last 2,6 or $18 \mathrm{~h}$ of the $24 \mathrm{~h}$ incubation with genistein. At the end of incubation, the reaction was stopped by placing the tissue on ice. After protein extraction and separation as described above the gels were dried in a Gel-drier and then exposed to X-ray film for $24 \mathrm{~h}$.

\section{Solutions}

The Krebs-buffered solution had the following composition (in $\mathrm{mM}$ ): $\mathrm{KCl} 4 \cdot 7, \mathrm{NaHCO}_{3} 15 \cdot 5, \mathrm{KH}_{2} \mathrm{PO}_{4} 1 \cdot 2$, $\mathrm{MgCl}_{2} 1 \cdot 2, \mathrm{NaCl} 122$, glucose 11 . The SDS sample buffer was of the following composition: Tris $\mathrm{HCl} 62.5 \mathrm{mM}$ (pH6.8), 2\% SDS, 10\% glycerol, $1 \mathrm{mM}$ phenylmethylsulphonylfluoride. For protein separation using SDS-
PAGE, 2-mercaptoethanol (final concentration 5\%) and bromophenol blue (final concentration 0.001\%) were added.

\section{Chemicals}

Genistein and $17 \beta$-oestradiol were from Sigma Chemical Co. ICI 182780 was a kind gift from Zeneca Pharmaceuticals, Macclesfield, Cheshire, UK. L- $\left[4,5-{ }^{3} \mathrm{H}\right]$ Leucine, methyl- $\left[{ }^{3} \mathrm{H}\right]$ thymidine, and $\left[{ }^{35} \mathrm{~S}\right]$ methionine were from Amersham, Amersham, Bucks, UK. Genistein, 17 $\beta$ oestradiol and ICI 182780 were dissolved in dimethyl sulphoxide (DMSO). Controls received DMSO $(<0 \cdot 1 \%)$ as vehicle.

\section{Statistics}

Values are means \pm S.E.M. Student's two-tailed $t$-test for unpaired comparisons was used to determine statistical significance. For multiple comparisons, the Bonferroni correction was used. $P$ values less than 0.05 were considered to denote statistical significance.

\section{Results}

As seen in Fig. 1A, nuclear immunoreactivity towards ER $\beta$ was observed in smooth muscle and in endothelial cells of mouse aorta. In ovx mice, vascular expression of ER $\beta$ was similar to that of unoperated animals (Fig. 1C). No immunoreactivity was observed after omission of the ER $\beta$ antibody (Fig. 1B, D). No immunoreactivity towards ER $\alpha$ was observed in either smooth muscle or endothelial cells of unoperated and ovx animals (Fig. 2A, B). In Fig. 2C, a positive control (uterus) for ER $\alpha$ is shown. Immunoreactivity towards ER $\alpha$ was observed in glandular epithelial cells and in stroma cells of the endometrium.

Activation of vascular ER $\beta$ with genistein $(100 \mathrm{nM})$ stimulated protein synthesis by $26 \%$ as measured by $\left[{ }^{3} \mathrm{H}\right]$ leucine incorporation (Fig. 3A). This effect was inhibited by the pure ER blocker ICI 182780. Total vascular protein concentration was not changed by genistein treatment (Fig. 3B). In addition, prolonged (48 h) treatment with genistein had no effect on total protein $(0.054 \pm 0.004 \mathrm{mg}$ protein $/ \mathrm{mg}$ tissue in genistein treated, compared with $0.046 \pm 0.003 \mathrm{mg}$ protein $/ \mathrm{mg}$ tissue in controls; $n=6)$. High concentrations $(10 \mu \mathrm{M})$ of genistein caused a decrease $(P<0 \cdot 05)$ in $\left[{ }^{3} \mathrm{H}\right]$ leucine incorporation of about 40\% (463 $000 \pm 64000$ d.p.m./mg tissue in treated mice and $768000 \pm 94000$ d.p.m./mg tissue in controls; $n=4)$. Combination of $10 \mu \mathrm{M}$ genistein with $17 \beta$ oestradiol $(10 \mathrm{nM})$ had no effect $(717000 \pm 104000$ d.p.m./mg tissue in treated mice and $768000 \pm 94000$ d.p.m./mg tissue in controls; $n=4)$.

The optical density of protein bands $(10-200 \mathrm{kDa})$ separated by SDS-PAGE was not different in genistein- 
treated and control tissues (Fig. 4A). In order to identify those protein bands in which new synthesis occurred after stimulation with genistein, separation of $\left[{ }^{35} \mathrm{~S}\right]$ methioninelabelled proteins $(10-200 \mathrm{kDa})$ by SDS-PAGE was performed. The autoradiographs were analysed by determination of the optical density of the different protein bands. Radiolabelled methionine was present for 2, 6 and $18 \mathrm{~h}$ of the $24 \mathrm{~h}$ incubation time. At 2 and $6 \mathrm{~h}$, weaker incorporation of radiolabelled methionine was observed compared with that at $18 \mathrm{~h}$. No genistein-stimulated $\left[{ }^{35} \mathrm{~S}\right]$ methionine incorporation was detected at any time point (Fig. 4B).

In order to investigate the effect of genistein on vascular growth, we measured incorporation of $\left[{ }^{3} \mathrm{H}\right]$ thymidine into DNA. As seen in Fig. 5, genistein $(100 \mathrm{nM})$ had no effect on DNA synthesis, whereas the well-known growth factor, fetal calf serum, stimulated $\left[{ }^{3} \mathrm{H}\right]$ thymidine incorporation by two to three times.

Vascular protein expression in ER $\beta$-knockout $(-/-)$ and wild-type $(+/+)$ mice was tested by SDS-PAGE. Expression of $10-200 \mathrm{kDa}$ proteins was similar in aorta from $-/-$ mice and in aorta from their wild-type litter mates (Fig. 6). Analysis of protein bands by determination of optical density did not reveal any differences in protein expression between $-/-$ and $+/+$ animals.

\section{Discussion}

ER $\beta$ seems to be the predominant ER isoform expressed in the rat and human vascular wall (Hodges et al. 2000, Andersson et al. 2001, Critchley et al. 2001). As shown in the present study, this seems also to be the case in mouse vascular tissue. We report here that activation of mouse aorta $\operatorname{ER} \beta$ with the selective $\operatorname{ER} \beta$ agonist, genistein, in $\mathrm{nM}$ concentration caused a $30 \%$ increase in protein synthesis as determined by $\left[{ }^{3} \mathrm{H}\right]$ leucine incorporation, but no change in total protein determined either by a modified Lowry method on tissue homogenate or by densitometric scanning of protein bands separated by SDS-PAGE. The increase in protein synthesis was ER-dependent, as it could be blocked by the ER antagonist, ICI 182780 . Protein synthesis determination using $\left[{ }^{35} \mathrm{~S}\right]$ methionine labelling and SDS-PAGE did not disclose any protein bands with increased incorporation. Thus it remains an open question which proteins in the vascular wall are regulated by ER $\beta$. Genistein had no effect on DNA synthesis, showing that activation of ER $\beta$ causes no stimulation of vascular growth. This suggests that activation of ER $\beta$ causes a specific stimulation of protein synthesis, which is not part of a growth response.

Genistein is an isoflavonoid phytoestrogen present in, for example, dietary soy. Genistein binds to $\operatorname{ER} \beta$ nearly as well as does $17 \beta$-oestradiol, whereas its affinity for ER $\alpha$ is much lower than that of $17 \beta$-oestradiol (Kuiper et al. 1998). Genistein has more than 20 times greater affinity for $\operatorname{ER} \beta$ than for ER $\alpha$, and studies based on competition between genistein and radiolabelled $17 \beta$-oestradiol for ERs $\alpha$ and $\beta$ have shown that $\mathrm{nM}$ concentrations of genistein preferentially activate $\operatorname{ER} \beta$ (Kuiper et al. 1998). It may be argued that genistein not only activates $\operatorname{ER} \beta$ but also inhibits protein tyrosine kinases. In vascular smooth muscle cells, genistein blocks tyrosine kinase-dependent events such as proliferation and contraction (Epstein et al. 1997, Nelson et al. 1997, Schonherr et al. 1997). To obtain these effects, however, one needs much greater concentrations $(>10 \mu \mathrm{M})$ of genistein than those necessary for activation of ER $\beta$. Here, we have observed that genistein increased protein synthesis in $\mathrm{nM}$ concentrations, involving activation of ER $\beta$, but decreased protein synthesis in $\mu \mathrm{M}$ concentrations, involving effects on both ER and tyrosine kinases. Interestingly, the effect of high concentrations of genistein was counteracted by $17 \beta-$ oestradiol. The stimulation of protein synthesis by $\mathrm{nM}$ concentrations of genistein, observed in this study, was prevented by the ER blocker ICI 182780, strongly suggesting that genistein exerted its effect through ER $\beta$ and not through tyrosine kinase inhibition.

Protein separation by SDS-PAGE using gels that give good separation of proteins in the range of 10-200 kDa did not reveal any differences in protein expression, as determined by analysis of band optical density, between aorta from ER $\beta$-knockout and wild-type mice. One explanation could be that ERs $\beta$ and $\alpha$ regulate expression of the same proteins, and that ER $\alpha$ takes over if $\operatorname{ER} \beta$ is absent. We have previously shown that aorta from ER $\beta$ knockout and wild-type mice, respectively, is equally sensitive to noradrenaline (Nilsson et al. 2000). ER $\beta$ is thus not the sole crucial factor for the expression of proteins involved in the regulation of vascular contractility, indicating some degree of redundancy of ER $\alpha$ and ER $\beta$ function in the vessels. Further studies using $\operatorname{ER} \alpha-\operatorname{ER} \beta$ double-knockout mice should help clarify this issue.

\section{Acknowledgements}

We thank Christina Andersson, Karin Jansner and Ina Nordström for skilled technical assistance. This study was supported by grants from the Swedish Medical Research Council (04X-13017-01A), The Swedish Heart and Lung Foundation, the Swedish Cancer Fund, Karo Bio AB, and the foundations of Åke Wiberg and Magnus Bergwall.

\section{References}

Andersson C, Lydrup M-L, Fernö M, Idvall I, Gustafsson J-Å \& Nilsson B-O 2001 Immunocytochemical demonstration of oestrogen receptor $\beta$ in blood vessels of the female rat. Journal of Endocrinology $169241-247$

Critchley HO, Brenner RM, Henderson TA, Williams K, Nayak NR, Slayden OD, Millar MR \& Saunders PT 2001 Estrogen 
receptor beta, but not estrogen receptor alpha, is present in the vascular endothelium of the human and nonhuman primate endometrium. Journal of Clinical Endocrinology and Metabolism 86 1370-1378.

Epstein AM, Throckmorton D \& Brophy CM 1997 Mitogen-activated protein kinase activation: an alternate signaling pathway for sustained vascular smooth muscle contraction. Journal of Vascular Surgery 26 327-332.

Grandien K, Berkenstam A \& Gustafsson J-Å 1997 The estrogen receptor gene: promoter organization and expression. International Journal of Biochemistry and Cell Biology 29 1343-1369.

Green S, Walter P, Kumar V, Krust A, Bornert J-M, Argos P \& Chambon P 1986 Human oestrogen receptor cDNA: sequence, expression and homology to v-erb-A. Nature 320 134-139.

Greene GL, Gilna P, Waterfield M, Baker A, Hort Y \& Shine J 1986 Sequence and expression of human estrogen receptor complementary DNA. Science 231 1150-1154.

Hodges YK, Tung L, Yan XD, Graham JD, Horwitz KB \& Horwitz LD 2000 Estrogen receptors alpha and beta: prevalence of estrogen receptor beta mRNA in human vascular smooth muscle and transcriptional effects. Circulation 101 1792-1798.

Iafrati MD, Karas RH, Aronovitz M, Kim S, Sullivan TR Jr, Lubhan DB, O’Donnell TF Jr, Korach KS \& Mendelsohn ME 1997 Estrogen inhibits the vascular injury response in estrogen receptor $\alpha$-deficient mice. Nature Medicine 3 545-548.

Krege JH, Hodgin JB, Couse JF, Enmark E, Warner M, Mahler JF, Madhabananda S, Korach KS, Gustafsson J-Å \& Smithies O 1998 Generation and reproductive phenotypes of mice lacking estrogen receptor $\beta$. PNAS 95 15677-15682.

Kuiper GGJM, Enmark E, Pelto-Huiko M, Nilsson S \& Gustafsson J-Å 1996 Cloning of a novel estrogen receptor expressed in rat prostate and ovary. PNAS 93 5925-5930.

Kuiper GGJM, Lemmen JG, Carlsson B, Corton JC, Safe SH, Van der Saag PT, Van der Burg B \& Gustafsson J-Å 1998 Interaction of estrogenic chemicals and phytoestrogens with estrogen receptor $\beta$. Endocrinology 139 4252-4263.

Lindner V, Sung KK, Karas RH, Kuiper GGJM, Gustafsson J-Å \& Mendelsohn ME 1998 Increased expression of estrogen receptor- $\beta$
mRNA in male blood vessels after vascular injury. Circulation Research 83 224-229.

Lowry OH, Rosebrough NJ, Farr AL \& Randall RJ 1951 Protein measurement with the Folin phenol reagent. Journal of Biological Chemistry 193 265-275.

Mäkelä S, Savolainen H, Aavik E, Myllärniemi M, Strauss L, Taskinen E, Gustafsson J-Å \& Häyry P 1999 Differentiation between vasculoprotective and uterotrophic effects of ligands with different binding affinities to estrogen receptors $\alpha$ and $\beta$. PNAS 96 $7077-7082$.

Mendelsohn ME \& Karas RH 1999 The protective effects of estrogen on the cardiovascular system. New England Journal of Medicine $\mathbf{3 4 0}$ 1801-1811.

Muramatsu M \& Inoue S 2000 Estrogen receptors: how do they control reproductive and nonreproductive functions? Biochemical and Biophysical Research Communications 270 1-10.

Nelson SR, Chien T \& Di Salvo J 1997 Genistein sensitivity of calcium transport pathways in serotonin-activated vascular smooth muscle cells. Archives of Biochemistry and Biophysics 345 65-72.

Nilsson B-O, Ekblad E, Heine T \& Gustafsson J- $\AA 2000$ Increased magnitude of relaxation to oestrogen in aorta from oestrogen receptor $\beta$ knock-out mice. Journal of Endocrinology 166 R5-R9.

Saji S, Jensen EV, Nilsson S, Rylander T, Warner M \& Gustafsson J-A 2000 Estrogen receptors $\alpha$ and $\beta$ in the rodent mammary gland. PNAS 97 337-342.

Schonherr E, Kinsella MG \& Wright TN 1997 Genistein selectively inhibits platelet-derived growth factor-stimulated versican biosynthesis in monkey arterial smooth muscle cells. Archives of Biochemistry and Biophysics 339 353-361.

Shi SR, Key ME \& Kalra KL 1991 Antigen retrieval in formalinfixed, paraffin embedded tissues: an enhancement method for immunohistochemical staining based on microwave oven heating of tissue sections. Journal of Histochemistry and Cytochemistry 39 741-748.

Received 17 August 2001

Accepted 24 August 2001 